
internationales

vol. $21-n^{\circ} 3 \mid 2005$

Familles, destins personnels et appartenances

collectives en migration

\title{
Sources of Aid and Resilience and Points of Pain in Jamaican Migrant Families
}

\section{Paul Thompson and Elaine Bauer}

\section{(2) OpenEdition}

12 Journals

Electronic version

URL: https://journals.openedition.org/remi/2502

DOI: 10.4000/remi.2502

ISSN: $1777-5418$

\section{Publisher}

Université de Poitiers

\section{Printed version}

Date of publication: 1 December 2005

Number of pages: 9-26

ISBN: 2-911627-45-8

ISSN: 0765-0752

Electronic reference

Paul Thompson and Elaine Bauer, "Sources of Aid and Resilience and Points of Pain in Jamaican Migrant Families", Revue européenne des migrations internationales [Online], vol. 21 - n³ | 2005, Online since 01 December 2008, connection on 14 April 2022. URL: http://journals.openedition.org/remi/ 2502 ; DOl: https://doi.org/10.4000/remi.2502

This text was automatically generated on 14 April 2022.

(c) Université de Poitiers 


\title{
Sources of Aid and Resilience and Points of Pain in Jamaican Migrant Families
}

\author{
Paul Thompson and Elaine Bauer
}

Notes: We owe particular debts for suggestions and information to Catherine Hall, Harry Goulbourne and Mary Chamberlain, for help in contacting families to Anthony Henry and Holger Henke, and for financial support to the Canadian High Commission in London, the Department of Sociology of the University of Essex, the British Academy, and most notably, to the Institute of Community Studies, London.

Most of all, we wish to thank those who shared their life stories with us for the essential help which they have given us. With the exception of one informant who wished to be directly attributed, all those quoted are given pseudonyms in order to protect confidentiality.

1 Scattered across the seas between the Caribbean, island Britain and the North American continent, more often than not divided by parental separations as well as vast distances, Jamaican transnational families may seem to fit all too well into the white social worker's image of the classically dysfunctional and literally "broken" family. As indeed with all stepfamilies, white as well as black, there is much less awareness of the far larger numbers of families who continue to function well enough without the support of case workers, or even generate men or women who make outstanding contributions to the wider society - including, in the past, Isaac Newton and Leonardo da Vinci among them. Still more rarely are Jamaican transnational families viewed, as they can be, as harbingers of the future which faces all of us in the Americas and Europe: as families pioneering the skills of living with remarriage as a normal feature of family life, and also of interracial unions, and of living globally, maintaining kin contact and help over vast distances ${ }^{1}$.

2 Our own aim is to understand more clearly, through an in-depth view of a small number of non-clinical families, both the sources of strength and resilience in such families, and also their points of loss and pain. Our current study is based on life story interviews with up to five members of the same forty families in the different 
continents, and where possible also participant observation at family occasions ${ }^{2}$. We bring different skills to the project. Elaine Bauer combines the perspectives of an anthropologist with the personal experience of a childhood in Jamaica and migration to Canada. Paul Thompson has worked for thirty years with the life story method, with a particular interest in changing family relationships (Thompson, 2000; Bertaux and Thompson, 1993;1997). His research has included a sample-based study of fifty British stepfamilies (Gorell Barnes, Thompson, Daniel and Burchardt, 1997).

3 The picture which emerged from that stepfamily study was not only of much real grief, but also of resilience: most of these stepfamilies worked reasonably well, and most of the stepchildren, now in their thirties, had succeeded in pulling their lives together, even though some of them were by now themselves divorced. More than this, they showed an unexpectedly high rate of upward occupational mobility. From this and also from the evidence of other projects it would seem that marital separations generate success stories as well as social work cases: fliers, as well as fallers. We have wanted to understand the workings of such complex families better: on the one hand to help those who do work with them as cases, but on the other because we may be able to learn positively from their ways of handling issues which have been part of Caribbean family life for generations.

\section{The context of jamaican migration}

4 For more than three centuries migration has been central to the consciousness of Jamaicans. Its present people are the mixed descendants, primarily of black slaves brought from Africa to work the sugar plantations, but also of white colonists, Indian indentured labourers, Jewish and Chinese traders, all migrants. Moving on, or return migration, were part of their dreams even in the 18th century. Today, for West Indians 'travelling' abroad is seen as a normal part of growing up, and often part of the transgenerational family story (Chamberlain, 1997). Although migration statistics are not reliable enough for precise figures, it is said that half of all Guyanans live as migrants abroad, while the two and a half million Jamaicans in Jamaica are probably matched by a million to a million and a half living overseas.

How much is already known about these transnational families ${ }^{3}$ ? There are no statistics concerning transnational families as such, since information is invariably drawn from separate national studies. Nor are there any really satisfactory units of analysis, given that parenting and sexual relationships may be conducted within the same "co-family" (Smith, 1988) but between different households. Nevertheless the national figures make it clear that Jamaicans everywhere have for generations tended to marry late if at all, and also that they have a high rate of female-headed households, twice that in the white British or North American populations. But West Indian migrants, especially women, also have a high rate of employment, and hence they are far from being the poorest immigrant groups in either Britain or North America (Berthoud, 2002).

In terms of qualitative research, most of the information again focusses on particularly countries, and above all on Jamaica itself. The unconventional features of Caribbean families have long been noted, and usually strongly disapproved, first by travellers and later by researchers. This disapproval focussed earlier on interracial sex, but comment then shifted onto the prevalence of female-headed households, and of multiple unions creating complex stepfamilies. Sometimes these are presented as survivals from 
African polygamy, sometimes as deformations resulting from the cumulative West Indian history of slavery, migration and poverty (Patterson, 1982). We see the Jamaican family system as emerging, perhaps partly as an emulation of the white plantation elite for whom multiple extramarital relationships were the normal pattern; but primarily as a necessary defence under slavery, when couples or parents and children were always vulnerable to being parted by sale. But whatever their historical origin, both female-headed households and multiple unions have been generally assumed as fundamentally disadvantageous, and threatening to the wider community as seedbeds of deviance and delinquency.

7 It is only during the last dozen years - and not by accident, precisely when for the first time divorce, single mothers and stepfamilies have become normal rather than exceptional in Anglo-American families too - that Caribbean family structures have begun to be interpreted more positively. Fortunately in Jamaica itself there have been some notable and relatively sympathetic studies, of which Edith Clarke's My Mother Who Fathered Me (1957), and Raymond Smith's Kinship and Class in the West Indies (1988) are outstanding. Regrettably there has been little recent work of such scope on Jamaican families in Britain since Sheila Patterson's Dark Strangers (1963), and in North America most research has focussed - often controversially - on black American families rather than West Indians. Nevertheless, for Toronto we have Frances Henry's, The Caribbean Diaspora in Toronto: Learning to Live with Racism (1994),and there also a small literature on Jamaicans in New York, including most recently Mary C. Waters, Black Identities: West Indian Immigrant Dreams and American Realities, Harvard University Press, Cambridge Ma, 1999.

Given that interest in the transnational family is new, it is hardly surprising that little has been published on this. This new view of the Caribbean family has emerged in the wider context of a much more general growth of interest in transnational and hybrid cultures. In particular, Robin Cohen has explored a range of "travelling cultures" in his Cultural Diasporas (1997), and Paul Gilroy the transnationalism of Caribbean culture in The Black Atlantic: Modernity and Double Consciousness (1995). For our concerns, the most important research on the transnational family is on migrants between the West Indies and Britain, by Harry Goulbourne and Mary Chamberlain (Goulbourne, 1999, and Chamberlain, 1997).

9 There has, however, been no transnational study of Caribbean families which encompasses their connections and exchanges of help across the whole transcontinental Atlantic triangle. This is our own aim. What are our interviews suggesting?

\section{Transnationalism and family bonds}

10 Firstly, for these families transnationalism is not a figment of the social scientist's imagination, but a reality both in the mind and in practice. Obviously the continual fracturing, both in terms of migration and sexual unions, means that contacts are often lost, and there are often gaps in people's knowledge. In any case it is only practicable to keep in active touch with a limited number of kin over such distances. But people were certainly always aware of their Jamaican, British and North America relatives and usually in touch with some of them. 
11 These families are rarely easy to delineate. The starting point of one of our first families was four half-sisters by the same mother, each with different fathers who had other children. The fathers of two of them had altogether some thirty children from at least ten different mothers. It is impossible to compress this kind of family into the spaces of a conventional Anglo-American family tree. It may require a long discussion to unravel precisely how two people are related. Selvin Green recalls how as a child in Jamaica he went to school with "many, many cousins by my mother's side... Some of them I can't even remember their names, there's so many of them." Quite often because of distance or breaches the whole kin network cannot be known. Thus Yolande Woods grew up in Britain believing that she belonged to an unusually small Jamaican family, and only as an adult discovered she had a "mega-family" of relatives in rural Jamaica. This means that there is always the possibility of unfinished business in setting out these kin patterns: someone unexpected who may suddenly be discovered, or come "knocking at her door" (Connie Dixon). These are kin systems which more than usually are continually on the move.

The sheer difficulties of comprehending such kin links may be one possible reason why Jamaicans tend to simplify. Typically, they do not distinguish half from full siblings, and they call aunts cousins or vice versa with little concern. But when one looks more closely, it becomes apparent that this imprecision is in fact a distinctive structural feature of the Jamaican kinship system.

13 It is particularly striking that in the Jamaican countryside this broad concept of family has been paralleled in practice by a traditional usage of "family land," on which any member of the family has a right to come and live - thus creating both a bond and also sometimes a source of conflict. Family land is freehold land, most of which was acquired by former slaves in the post-emancipation period. It is usually transmitted by custom rather than formal law, and all recognized descendants through both sexes of its original owners have accepted rights to use it and to build a house on it. The land is transmitted undivided, so that the co-heirs have joint rights to the whole rather than actual pieces of it. It is also traditionally regarded as inalienable, particularly since in many cases family members are buried there, so that their graves give an element of sacredness to the family land. In practice, however, priority is given to those family members who are most in need, while those who have migrated or otherwise done better are expected to suspend their claims. Nevertheless these absent members are recognized as having a latent right to return to use the land, for example on retirement. "Thus it is the entitlement to freehold land which is the crucial aspect of family land, rather than the activation of such rights" (Besson and Momsen, 1987: 15). In short, in terms of land, "family" is seen as encompassing all those descended from the same ancestors, with no formal or gender distinctions accepted between them in terms of rights, but prioritization based on individual need and circumstance. This concept closely matches the working of the kin system in other ways: for example, while most migrants feel an obligation to send regular money and gifts home, they are likely to focus on those they feel are most in need. Thus one New York Jamaican sends remittances not to his mother, but to a younger sister: "Of all the family members, she is the one who is struggling most to make ends meet".

Hence we view this combination of complexity with uncertainty not as a sign of pathology or "stretching" in the kin system, or because common Jamaican family forms are "incomplete", "denuded" or "disintegrate", as too many earlier researchers have 
interpreted Caribbean family relationships (Barrow 1996: 9-17, 61), but as a positive characteristic of the system, which enables its resilience in supporting family members. The flexibility of Jamaican kin relationships is empowered by their pragmatism and informality.

Thus gradually one begins to see that within this familialism there is also an equally crucial individuality. Kin networks in any families have to be seen from the starting points of individuals, but re-partnering means that the resulting kin maps are likely to differ much more sharply, even between siblings. In the face of this, on the one hand people accept the possibility of help from many directions, so that Dahlia Noble remembers feeling no sense of loss when as a child she moved on the death of her grandmother to a great-aunt: she felt secure because she was "still within the family circle." At the same time, however, particularly for adults, there is a sense that kin relationships need to become real through significant social contact and potential or actual exchanges of help.

Hence fathers who have abandoned their offspring are largely disregarded, and may not find it possible to win back a parental relationship later in life. Blossom Grant's father, who lived in America and had no contact with her as a child, came to find her when she was 27: "He tried to give me material things, but that's not all... He wasn't there for me when I was small... I didn't have any love for him as a father."

The complexity of attitudes to half-siblings can be understood in a similar way. Sarah Chisholm was brought up in Jamaica belonging to a family of twelve full and halfsiblings on both her father's and her mother's sides. She declares forcefully:

We are very close, and I don't refer to them, I don't consider them as half-brothers or half-sisters. They are my sisters, they are my brothers, irrespective of whether we share the same mother: they are my sisters. I think it's ridiculous people talking about, "That's not my full brother. He's my half-brother." I think that's - very low.

But she does in fact make some clear distinctions. She recalled of her eldest sister, "at one time I thought she was my mother, because she was very very caring." And particularly strikingly, when her father adopted the sister of a half-sister abroad who was not a blood relative, she was able to treat her as a full sibling: "the bond is so close, so tight... that eventually you say, 'Oh this is my sister...' We had that closeness." In both of these instances one can see how one formal relationship can be substituted for another for positive reasons.

On the other hand, she also says later that she is not close to two older sisters who were abroad when she was a child. It seems clear that half-siblings who were not known in childhood could eventually be disregarded as kin, particularly when their common parent had not maintained regular contact. Isabelle Woods' father, who had been in little contact and provided scarcely any support for her as a child, reappeared when she was twenty and told her, "You'll have to meet your stepbrothers and sisters." But she felt no interest in meeting them: "Not at all. Like I told him, 'I'd rather get to know him first, before I start to learn about the rest of the family." She could not get on with him and has been out of touch for ten years, nor has she taken up contact with her halfsiblings. 


\section{Psychological impact on transnational families}

20 A similar pragmatism in attitudes helps to explain why the crucial points of pain in their lives of which our interviewees spoke were often not the separation from fathers or mothers, with the continuing sense of parental loss, which have been stressed by comparable studies of white stepfamilies (Gorell Barnes, Thompson, Daniel and Burchardt, 1997). In these Jamaican families three different primary sources of pain are highlighted.

21 There is, firstly, certainly a kind of grief intrinsic in migration itself, even when made in a spirit of hope for betterment. When she was 17 Verity Houghton's mother left for Canada, preparing the way for the rest of the family, but to Verity "It felt like someone - someone had died." Isabelle Woods' mother left London for New York when she was under 5, but she still remembers her distress: "I was bitter towards that. I didn't see the need for her to leave." Roy Cripps did not see or hear his mother for five years after she migrated ahead to England: "My mother - if I miss my mother dearly, dearly, I really did".

On the parental side, Stella Wadham remembered her four-year separation from her three-year-old daughter "It was tough. But I think I consoled myself by saying, 'I can give my child this... It was very tough." Sarah Chisholm similarly reflects on how she felt leaving her son in Jamaica as a small child when she went ahead to Canada:

The other most notable points of pain were from the loss of good older care-givers who died, and the fortunately not very common experience of being placed with an unsympathetic relative. It is clear that in most instances grandmothers proved more than adequate substitutes for mothers. Selvin Green stands for many others when he says, "I was pretty close to [my mother], although I was closer to my grandmother." Connie Dixon calls her grandmother "a saint." But because of their greater age grandmothers were more likely to die than mothers, and for Connie the day her grandmother died was "the first time I've ever felt my heart ache, and it was literally, my heart was aching."

Such a loss was still worse when it led to a new life with a much-disliked new caregiver. For Connie Dixon it was an aunt who would beat her violently and sent her own child to school while forcing Connie to work in the fields. Blossom Grant similarly was sent to an uncle whose wife favored her own two children, beating Blossom severely, discriminating against her in terms of food and clothing, and sending her to work in the bush while the other two were at school. Such aunts are described with the acute dislike usually reserved in family stories for wicked stepmothers.

There is, by contrast, rarely any emphasis on pain through absent or missing fathers. In general, when a father is absent but "owns up" to being a parent, exchanges photographs and sends occasional money and gifts to his children, his behavior is regarded as acceptable. The contact and gifts are seen not only as helpful but as important symbols of caring. Thus both Selvin Green and Nelson Pinnock describe how they sustained contact in this way with children they had left behind: "So it's continuous communication with barrels and letters and money. You just keep communicating. You can't lose track of them."

By contrast, fathers who failed to maintain contact seem on the other hand to have eventually lost potential emotional significance. Charlene Summers was not much moved when in her thirties she heard that her father, whom she had never known, had 
been searching the local Jamaican countryside looking for her. She did not trace him at the address in Kingston which he left. "My father is not a problem for me... I don't force it. Because if it is God will, some day I will know him... If I see my father now, I'll prefer ask him to help my two kids than even me, right?" Yolande Woods, who grew up with her grandmother in London, stands for many when she reflects, "It would have been a lot more disruptive for us... It probably would have been a lot more headache if he'd been around, by virtue that I grew up in a very stable environment... I felt protected... I missed the role. I don't miss him." There are many missing fathers in these life stories, but not one whose absence was described as a major source of grief, pain or longing.

\section{The strengths of transnational kinship-networks}

Just as grief in Jamaican transnational families takes on particular configurations reflecting their kin structure, so do the sources of resilience and strength which they reveal. Inevitably the message of these life stories is mixed, with many accounts of effective kin mobilization to help relatives, but also instances, particularly among migrants, of feelings of isolation. Thus Linton Black nostalgically describes a Jamaican childhood where he was part of a large extended family living close together: "We all took part in looking after each other. Well, they see to it that I didn't get in trouble, and if I do get in trouble, they was there to help me out." Now he is in the United States he has just one cousin who visits occasionally, and says he would "turn to him" in a difficulty, but it wouldn't be like that back home. There "it would be a family surrounding, as most of my family would be around me."

Migrant women were particularly likely to feel that contrast at times of childbirth. Sarah Chisholm, who had a first child in Jamaica and two later in Canada, recalls how in Jamaica "I had a sister, a mother, two nieces... and the neighbors, and the community, that would come by, who would wash the clothing for the child, who would want to take him for a walk... Here it's a different story. You have your children all on your own."

Equally striking, however, is the resilience of the kin system. The most extreme instances are those in which it seems that migrants have succeeded in recreating a Jamaican neighborliness within their new context: a reinventing of tradition in new forms, which is sometimes quite deliberate. Thus Arnold Houghton describes his situation in Toronto:

Two sisters close by. Parents not far away. It used to be like every Saturday, we just hang out at mother's... We still get together quite a lot, unrehearsed. You just pick up and end up at J's, and then you might end up at Verity's. My parents I see at least twice, sometimes three times a week, sometimes every day, because I might pop by at lunchtime.

When Tracey Scott moved to Florida five years ago, there were already kin in three other houses in the same road, the homes of an aunt, and uncle and a grandmother.

Such regrouping does not just involve immediate family. One particularly remarkable migrant woman seems not only to have recreated a community for herself through friends as well as kin, but to have done this successively in three different locations. As Yolande Woods puts it:

When [my mother] left Jamaica, and she went to England, there were friends that came around the same time, lived in the same area. When she left England, she 
moved to the Bronx, I remember the whole street was like full of people that we knew back in England... And then when she decided to move down to Florida, she was one of the first ones to move down there. Now, every time you go there she goes, "Oh yeah, do you know Blablabla moved down here?" It's like she's created this little community for herself.

31 However, given that we are concerned with geographically mobile migrant families, some of whose members are always likely to be contemplating another move, such regroupings cannot provide the mainstay of kin support. The four most typical forms of kin help are firstly, practical assistance in migrating; secondly through sending financial remittances, usually to kin in Jamaica; thirdly, help with child-rearing, very often to enable a young mother to work or to migrate; and fourthly, caring for older kin. All these exchanges of help operate on a transnational basis.

Practical help in migrating - including paying for tickets, providing an initial home, and help in finding work - is the normal practice in most of these families; and similarly, remittances in the form of money and gifts are sent back to kin in Jamaica by most migrant families - and by both men and women.

Caring for the old who are left behind in another country is a form of help which is mentioned much less often, by at most a quarter of these families. Sometimes migrants were at pains to ensure that a parent was receiving proper care; in other families a younger member returned to Jamaica to live with them. The response to the old depended, in key with Jamaican kin relations more generally, very much on whether any feeling of reciprocal obligation had developed. Thus David McNeep, now sick and in his 80s in England, had ten children in Jamaica and Canada, but he had abandoned all but one and none was now willing to come to take care of him. By contrast Louis May had been brought up by his grandmother, and when the family called from Jamaica to England to tell him that she had suffered a stroke, "I had to grab everything, everything, and spend the next night coming, on the plane to Jamaica. And I tell you after this stage, because the thing is that I had to lift her up like a baby.. And what came back to me is what she used to do to me when I was a baby".

Help with children, by contrast, is a much more common form of mutual aid. Child fostering among kin, either temporary or permanent, is a very widespread practice in Jamaican families, probably dating back at least to the slave era. Sometimes it is a response to a disaster, such as a parental death; but more often it is a positive strategy chosen so as to help the young adult parent to get into work, or to go ahead as a migrant. Some children are sent back to kin in Jamaica in the hope of a better education. The initiator can be either the parent, or the grandparent, or occasionally the child. Thus Stella Wadham in Jamaica as a child was initially "borrowed" by her grandmother, for a few days, but once there she effectively insisted on staying, by refusing to eat whenever she was returned to her mother; and Stella in turn chose to leave her two young daughters behind when she migrated to New York. And Greta Houghton's Jamaican mother must have specially liked the role of fostering:

My mother actually raised, took care of other people's children, who might not have been relatives of hers, immediate relatives..., who would have come in and ask her, somebody might be migrating to England, a mother might be migrating to England and ask her to let the children stay for a little while, so she did that too.

We have found this "child-shifting" operating in almost all of our families, and in over half of them there are transnational instances. 
Childcare is typically provided by a grandmother or aunt living nearby to enable the mother to leave to work, but it may be the care-giver who moves. When Isabelle Woods' mother decided to move from London to New York, she summoned their grandmother from Jamaica to fill the gap: who as a result committed herself to spending twelve years of her life in England. "It was a big decision my nan had to make, but she did."

While the key axis of exchanges of help is between parents, children and grandchildren, it is notable how the possibilities extend well beyond this. Aunts are common care-givers. Cousins are taken in to assist migrants. Remittances are sent not only to parents, but often also to siblings or to in-laws. Temporary help with migration may extend to very distant kin, including even ex-in-laws.

Underlying this is a sense not only of the potential importance of extended family kin, but also of how strong obligation with more distant kin can be built through individual life experiences. When Patsy Clark decided to migrate to the United States, she received crucial support not only from her mother's brother, who was already there and had been sending remittances to his nieces, but also from this uncle's ex-girlfriend, who had her to stay in her house, and found her a job.

In another family, as a child Sarah Chisholm had been particularly close to her eldest sister, who she describes as being like a mother to her, "a protector." When this sister died, Sarah brought two of these nieces to Canada, and indeed as one of them says has in turn played the role of a mother figure: "She's my mother, she took care of us after my mum died, and she has just been making sure that everything goes okay for us." Sarah herself is in no doubt why she has taken on this role, and explains precisely how she felt a clear reciprocal obligation to help her sister's children: “I brought them here, because of the kindness of my sister, of what she did for me. I thought it was necessary to return the kindness to her children."

These examples lead to a further point: the key role of women as activators of these kin networks. In contradiction to those who have argued that women are salient in Caribbean families only by "default" in "incomplete" families whose men are missing (Barrow 1996, 61) we have found women taking such roles whether or not husbands or fathers are present in their households. In general, while both men and women are likely to send financial remittances, not only caring but also the organizing of kin migration seem more likely to be the responsibility of women.

41 This means that in some families, even where men are present and significant, particular women become dynamic activating figures around whom the kin system revolves. Nelson Pinnock describes an aunt who "took" several family members to Canada as "the father of the whole family." For generations - perhaps back to the slave era, when women were already marketers for family produce - it is women in Jamaican families who have expected to take the strategic role, to "tink and plan." For the present generation, thinking and planning needs to be international as well as local. Thus Dana Howard, now a successful American accountant, describes her mother's strategic role in planning both the children's education and migration: 'It was she who 'basically helped to plan our careers... She's always been the person with a very global vision.'

Certainly there were also other families, where fathers had moved on, in which the men could seem still more marginal to the kin network's direction. As Yolande Woods' put it of her own family, whose scattering has been again led by her mother: "Men are really a sort of unspoken entity, phantom figures." Women "are the only thing that 
really [matters]. There's never been any real male role." One can see from these instances why Jamaicans might have coined the proverb, "mother blood is stronger than father blood"; and also why such dynamic kin systems, while definitely not either "matriarchal" or "matrilocal," can more plausibly be seen as depending on broader social processes in which "there was a salience of women," and therefore, as Raymond Smith has termed them, "matrifocal" (1988: 7-8).

\section{Young people in danger}

The extended family system which we have described focusses its support on children and the old, and can respond effectively to their crises. With children, for example, who are emotionally unsettled, or doing badly at school, it can enable a shift of context through a move to another family household or to another country. For example, Brigette Umber was desperately unhappy after migrating with her parents to New York at the age of 8: "I hated it. I hated it. It was the most awful experience of my life!...The schooling, the kids, the language, their behaviour. It was very depressing... I was so depressed, she [mother] had to send me back home." Brigette returned to her sisters in Jamaica for another two years, when she came to rejoin her parents in New York, this time successfully.

Very rarely, this same kind of help could be given to a young adult. Isabelle Woods had migrated from Britain to New York at 15, following her mother, and at 18 was living with a man who first she discovered was a gunman and then was imprisoned. Her mother immediately paid for her return ticket to London and her English friends: “'Look, I've got some money together. You're too young to go off your head, to have a nervous breakdown, so take this money and go home', she said. 'I know you'll be safe there." Isabelle flew back the next day, and the strategy worked: she is today a successful professional worker.

For young women, however, the commonest source of danger was to become an unsupported single mother. For them, the extended family system was especially effective, with kin support in childcare or child shifting enabling them to win economic independence through work and/or migration. It is precisely partly because of this help that Jamaican women in Britain are able to have a higher participation in the workforce than do British-born white women.

The situation is much more difficult for young black men, and it would seem too that there is less effective help available for them from their families. Indeed, we have so far no instances of such help being provided. Their fundamental difficulty is that boys perform less well at school than girls, and partly because of this, as well as raciallybased apprehensions among employers, it is less easy for them to get work than for young black women. But their families can do nothing about this fundamental problem. Worse still, it can be argued that faced by this structural employment situation, because their families are so matrifocal, it is difficult for a young man who is not an earner to hold a respected role in them - for example as a carer or house-husband. A young man out of work thus has to choose between the values of a family which is unable to offer him a role, and the values of his peers - the common masculinity of all ethnic working class groups: a scorn of education, and an admiration for physical prowess, including sport, sexuality, and fighting. Nor, alternatively, is it practicably possible for the family to exercise the severe discipline, which is the traditional remedy 
of for disobedient children, on the small minority of tough young male kin who become involved in drugdealing, guns and violence.

Four of our interviewees, two in Jamaica and two in Britain, have become part of this deviant sub-culture. With three of them this does not look to come from failures in family relationships, but on the contrary, from models within their families which proved misleading. Selassie Jordan's parents were both rastas when he was a child in Jamaica, and he remains especially close to his mother in New York. His most dangerous phase seems to have been after she migrated ahead of him, leaving Selassie with his father in Kingston, and the boys 'explore a lot, explore with guns, badness, all type of things'. Although still frequently into minor troubles with the police, Selassie has become a peace-loving transnational rasta small trader, "just a small, small man livin and livin around di system". Sid and Crichton Bell grew up in London with their mother, but their father was a regular visitor and a powerful influence, pushing them with their education. They also learnt from him, however, to steal, and when they were both caught and sent to prison he was annoyed only because they had been foolish enough to be found out.

Winston Lloyd, by contrast, certainly did have a very unsettled childhood. He moved between a loving grandmother, his mother, whom he feels "disrespected me." At 6 he was sent to his confrontational father, "a rough man", and his harsh stepmother, but ran away from them to a childless neighbour when he was 13. But Winston also took a his family model: his paternal grandfather, "a rough guy... He was like a vicious man. Now, I think, in this life, I think I live on his spirit". This grandfather was a gambler and a womaniser, violent and frequently in gaol. "Sometimes if I get really upset, is like I become like a different person. And they say is just like my grandfather used to operate".

Life has indeed proved hard for Winston. He has had a combination of jobs, which he has supplemented by growing a selling weed - and for his drug dealing and fights with the police has been imprisoned: "Me go a jail man, whole heap of times". He married a white Canadian woman, but that did not work out, and he has lost contact with their child. More recently, he has turned over a new leaf following a semi-religious vision and conversion, and is working as a driver. And especially interestingly, he is trying to realise family life as he believes it should be, rather than as he experienced it when younger. He is a very caring father to his two younger children. And above all, loyal to his mother's deathbed call, he has remained in close and supportive support of his six siblings (of whom one is a junior manager in Canada): "My mother left me to look over all of them. So I have to keep check. Yeah, she hold my hand and told me on her dying bed".

\section{Towards a new form of modern family}

50 Examining these life stories thus brings out how transnational Jamaican families have special features, particularly their flexibility in formal terms and the prominent role which they allow to women, which help them to mobilize aid through the kin network in ways which would be much less likely with white Anglo-American families. These strengths provide some mitigation of the pains of migration. In any case much of their fragmentation through migration is itself an active response to the poor economic situations from which they set out. Raymond Smith (1988: 183) concludes that earlier 
onslaughts on the fragmented mother-centered black family have been "grossly misplaced... There is no evidence that poverty is caused by family structure, and a good deal of evidence that kinship ties continue to represent the major ameliorating factor making life bearable among the urban poor."

How reasonable, however, is it to see these families as providing, not only vital mitigation of economic and social disadvantage, but also a progressive and pioneering "modern" family form which anticipates aspects of family life which will become much more generally common in the near future? Their willingness to give real power to women can indeed be seen as one instance of this. And there are three other senses in which we believe that this argument can be reasonably put forward.

The first concerns stepfamilies, which have been common in Jamaica for centuries, and are now a highly significant and rapidly growing minority in Britain and the United States. It does look as if the familiarity of parental separation and re-partnering has led to a healthily pragmatic approach to it from which important lessons could be learnt. These interviews suggest that there is much less long-term acrimony between expartners and rarely struggles over the possession of children, as well as much more readiness of kin, immediate or more distant, to step in to help single mothers with child-rearing.

There are of course, although the exception, some bitter experiences of suffering under unfair and harsh stepparents among the life stories which we have recorded. But at the other extreme Stella Wadham recalls an aunt in Jamaica as a transgenerationally inspiring stepmother, raising "several" of her husband's children by other women:

There's been situations with her husband, and she's just dealt with it so well. He has had outside children, during the marriage. And when push comes to shove, she ends up with the kids... She has been a lot of inspiration for almost all the kids she has raised, her husband's kids. She was just telling me that, Mother's Day, she got this big card, and this is one of his daughters that she grew, and she's now in Canada. Not hers. And she sent a letter in the card, and said to her, "Thank you for everything you did for me. Because now, what you did, has taught me how to deal with my husband's kids" - which is now her stepkids. Because each time anything happens, she just remember that she had taken her in, and she never treated her less than her kids.

We have here an explicit instance of how successful stepfamily norms can be transmitted to younger generations.

A second forward-looking quality of Jamaican families is their inter-racialism. Mixed race partnerships are of increasing importance both in Britain and in Canada. In Jamaica, while racist attitudes have also been common for centuries, so have mixed race unions. Now these contemporary Jamaican families can often be both transnational and interracial; and they do seem to have an openness of attitude which helps them to accept kin from other ethnic groups. For example, Nelson Pinnock was quite happy that one of his daughters has a white Canadian boyfriend, and explains with some pride, "I have four uncles married to four different nation men. One married to a Chinese, one married to a white - he died in England, one married to a black, and the other married to a Jamaican Indian." In some instances this is taken still further, to become a positive family ethic encouraging interracial relationships. Thus Isabelle Woods recalls how in her London childhood, "my grandmother, she always used to say, 'You mix. You always have to work a bit harder, but mix."” 

across national boundaries, and could be seen as pointing in a direction which our current conflict-ridden world might gain by following. In general migrant Jamaicans to Britain and to Canada (but not to the United States: Thompson and Bauer 2003) keep a double sense of identity and some have clearly thought long about this. Let us conclude with a final example, which, though unusual, may stand for the pioneering modernism of the Jamaican transnational family. It is a strikingly progressive perspective, transcending locally based double identities to form a vision of world citizenship in a shifting global economy. It comes from Arnold Houghton of our Canadian e-mail family:

I think the way the world is going... I don't see people being born in one place, growing up, spending all their life in one place... I'd like [my children] to see not just Canada as some place where they can live and grow up and make it, but they should be able to see the whole world as some place where they can explore and grow and achieve.

\section{Conclusion}

These then are our findings from the forty transnational Jamaican families whom we have studied. But what questions does our investigation suggest for further research? The first is how far such transnational families will prove transitory, a transitory moment in migration, or whether they will be sustained by continuing migration and 
remigration. We know that currently continuing migration is much more to North America than to Britain. It will be interesting to see what long-term impact this has on family forms.

A second parallel issue is how far some of the key Jamaican family patterns and values are sustained by the second and later generations. We have emphasised the pragmatic extended family structure within which help is given, the positive attitude to interracial mixing, and the very strong role of women. In both Britain and Canada we have observed these practices continuing, and also spreading into the general population through mixed marriages, but this needs much more research. Linked to this is the issue of masculinity, the role of men in the family, and the impact of this on young men. Given the rapid changes which have been normal in youth cultures, it will be very important to observe more closely how attitudes to masculinity evolve in the second and later generations of these migrant families, including the mutual exchanging of influences with majority youth cultures in Britain and North America.

Beyond these empirical issues there is a shortage of relevant theory on transmission in transnational families. On the one hand the classic anthropological studies of Caribbean families were more focussed on the transmission of African legacies than on the contemporary transmission of family culture. On the other hand, the general theorists of social capital who have studied intergenerational transmission have not so far been concerned with this kind of family. Thus James Coleman's model seems based on the white American family of the 1950s, while Pierre Bourdieu's more subtle interpretations are rooted in his understanding of the French middle class and elite. There is therefore a need to develop a theory of transmission in transnational families more generally, developed through comparison with empirical examples from different cultures, which can take into account the complexity and the often slender material base of these families, and how their family cultures can nevertheless be successfully transmitted, sustained and evolved.

\section{BIBLIOGRAPHY}

BARROW Christine (1996) Family in the Caribbean: Themes and Perspective, Oxford: James Currey.

BERTAUX Daniel and THOMPSON Paul (eds.) (1993) Between Generations: Family Models, Myths and Memories (International Yearbook of Oral History and Life Stories, 2), Oxford: Oxford University Press.

BERTAUX Daniel and THOMPSON Paul (1997) Pathways to Social Class, Oxford: Oxford University Press.

BERTHOUD Richard (2002) ‘Ethnic diversity and inequality’, ISER Newsletter, June: 3 BOURDIEU Pierre (1984) Distinction: a Social Critique of the Judgement of Taste, London: Routledge. BESSON Jean and MOMSEN Janet (1987) Land and Development in the Caribbean, London: Macmillan. CHAMBERLAIN Mary (1997) Narratives of Exile and Return, London : Warwick Caribbean Studies. 
CLARK Edith (1999) My Mother Who Fathered Me: a Study of the Family in Three Selected Communities in Jamaica, third edition, Kingston: University of West Indies Press (London: Allen and Unwin 1957, first edition).

COHEN Robin (1997) Cultural Diasporas, London: University College of London Press.

COLEMAN James S. (1990) Foundations of Social Theory, London: Harvard University Press.

GILROY Paul (1993) The Black Atlantic: Modernity and Double Consciousness, London: Verso.

GORELL Barnes, Gill and THOMPSON Paul, GWYN Daniel and BURCHARDT Natasha (1997) Growing Up in Stepfamilies, Oxford: Oxford University Press.

GOULBOURNE Harry (1999) “The transnational character of Caribbean kinship in Britain," in Susan McRae (ed.), Changing Britain: Families and Households in the 1990s, Oxford: Oxford University Press, 176-197.

HENRY Frances (1994) The Caribbean Diaspora in Toronto: Learning to Live with Racism, Toronto University of Toronto Press.

PATTERSON Orlando (1982) "Persistence, continuity and change in the Jamaican working class family," Journal of Family History 7, 135-61.

PATTERSON Sheila (1963) Dark Strangers; a Sociological Study of the Absorption of a Recent West Indian Migrant Group in Brixton, South London, London: Tavistock.

SMITH Raymond T. (1988) Kinship and Class in the West Indies: a Genealogical Study of Jamaica and Guyana, Cambridge: Cambridge University Press.

SMITH Raymond T. (ed) (1996) The Matrifocal Family, Routledge, London

THOMPSON Paul and Elaine BAUER (2000) 'Jamaican Transnational Families: Points of Pain and Sources of Resilience' in Wadabagei: a Journal of the Caribbean and its Diaspora, Summer-Fall, 1-37.

THOMPSON Paul and Elaine BAUER (2003) 'Evolving Jamaican migrant identities: contrasts between Britain, Canada and the United States', Community, Work and Family, 6, 1, 89-102

WATERS Mary C. (1999) Black Identities: West Indian Immigrant Dreams and American Realities, Cambridge, Mass.: Harvard University Press.

\section{NOTES}

1. An earlier version of this article was published in Wadabagei: a Journal of the Caribbean and its Diaspora, Summer-Fall 2000: 1-37

2. While there is no practicable sample base for a transnational study, we have sought a balance in terms of gender, age and occupations. The interviewees range in age from thirties to eighties, and from professional occupations to unskilled workers and unemployed. They were contacted in different ways: through the Jamaican Canadian Association, the Caribbean Research Center at Medgar Evans College, Brooklyn New York, our own personal networks, and through chance contacts in public.

3. We give a full review of the literature in English in the earlier version of this article (Thompson and Bauer, 2000). 


\section{ABSTRACTS}

This article is based on the evidence of life story interviews with members of 45 families who have kin in Jamaica, Britain and North America. It argues that the transnational Jamaican form of family is based on a complex but informal and pragmatic type of family structure which has characterised Jamaican kinship since emancipation from slavery. It has long been common for children to be raised by grandparents or other kin, whether because of parental repartnering or through separations due to migration. The article shows how this shifts the typical focus of psychological loss in migration, and enables effective aid to be sustained through the transnational kin network in childrearing, care for the old, and migration itself. It seems, however, that this support is least effective for young men in contrast to young women. Finally the authors argue that these Jamaican transnational families, because of their long experience with handling transitions from repartnering, the strong role which they give to women, their interracialism and transnationalism, are a progressive modern form of family of wide relevance to family researchers everywhere.

\section{Soutien, résilience et points douloureux dans les familles jamaïcaines transnationales.}

L'article se fonde sur des récits de vie recueillis auprès de membres de 45 familles qui ont de la parentèle à la fois en Jamaïque, en Grande-Bretagne et en Amérique du Nord. L'idée centrale est que la forme jamaïcaine transnationale de famille est centrée sur un type de structure familiale qui est complexe, informel, et pragmatique; ce type de structure serait caractéristique de la parenté jamaïcaine depuis la fin de l'esclavage. Il n'est pas rare que les enfants y soient élevés par leurs grands-parents ou par d'autres membres du réseau familial, que ce soit en raison d'une recomposition du couple parental ou à cause de séparations consécutives à une émigration. L'article montre comment ce phénomène redéfinit le sentiment de perte psychologique due à la migration; il permet un soutien efficace et durable du réseau familial transnational dans la prise en charge des enfants, des personnes âgées, et des migrants eux-mêmes. Il apparaît cependant que ce soutien est plus faible s'agissant des jeunes hommes que des jeunes femmes membres du réseau familial. Une des conclusions de l'article conduit à considérer ces familles jamaïcaines transnationales comme relevant d'une forme familiale moderne. Les caractéristiques de cette modernité - expérience acquise dans la gestion des transitions résultant de recompositions familiales; rôle important attribué aux femmes; caractères d'inter-racialité et de transnationalisme - constituent un type de modèle familial très contemporain et d'un grand intérêt pour l'ensemble des chercheurs du domaine.

Apoyo, « résilience " y puntos dolorosos en familias jamaicanas transnacionales.

El articulo se funda en « discursos de vida » de miembros de 45 familias cuyos lazos de parentesco atañen Jamaica, Gran Bretaña y América del Norte. La idea central consiste en analizar el modelo jamaicano de familia transnacional, modelo que se articula alrededor de una estructura familiar compleja, informal y pragmática. Este tipo de estructura familiar parece remontar al periodo en el cual fue abolida la esclavitud. Así, no resulta extraño por ejemplo que, a raíz de una recomposición de la pareja formada por el padre y la madre o bien de separaciones sucesivas ligadas a la emigración, los niños sean criados por los abuelos o por otros miembros de la red familiar. El artículo muestra cómo este fenómeno redefine el sentimiento de pérdida psicológica ligado a la emigración. La red familiar transnacional proporciona un apoyo eficaz y duradero de cara al cuidado de los niños, de las personas ancianas y de los propios inmigrantes. Sin embargo, este apoyo parece ser más débil en el caso de los hombres jóvenes que en el de sus homologas femeninas. Una de las conclusiones del artículo consiste en considerar a estas familias jamaicanas transnacionales como una forma familiar extremadamente moderna. Los factores que permiten 
avanzar esta modernidad son : la experiencia que estas familias poseen en materia de gestión de transiciones resultando de recomposiciones familiares, el importante rol que se otorga a las mujeres y la inter-racialidad y transnacionalismo de las familias. Se trata, en definitiva, de una forma familiar contemporánea de gran interés para los investigadores de todos los países.

INDEX

Mots-clés: éducation, entraide, famille, histoire de vie, relations familiales, réseaux transnationaux

Geographical index: Jamaïque

\section{AUTHORS}

\section{PAUL THOMPSON}

Research Professor in Sociology, University of Essex, and Senior Research Fellow, Institute of Community Studies, London

\section{ELAINE BAUER}

Research Fellow, Institute of Community Studies, London, and Ph D. candidate in Anthropology, Goldsmiths College, University of London 